\title{
Blastomycosis in Quebec (1981-90): Report of 23 cases and review of published cases from Quebec
}

G St-Germain, G Murray, R Duperval. Blastomycosis in Quebec (1981-90): Report of 23 cases and review of published cases from Quebec. Can $J$ Infect Dis 1993;4(2):89-94. Twenty-three cases of blastomycosis were reported in a survey conducted in the province of Quebec from 1981-90. Thirteen patients resided south of the St Lawrence River and the other 10, north. Two small geographical clusters were apparent in and around the cities of Sherbrooke and Quebec. The male to female ratio was 1.6:1 and the median age was 47 years (range 26 to 77). Lung involvement was observed in 19 cases and was the only site involved in 11. Cutaneous manifestations were reported in 11 cases while bone infection (three cases) and central nervous system (CNS) infections were also noted. Diagnosis was confirmed by culture in 21 cases and by histopathology in two cases. Of the 21 culture-positive cases, 12 strains of Blastomyces dermatitidis were isolated from lungs, nine from skin, and one each from bone and brain. Serodiagnostic tests by immunodiffusion or complement fixation were positive for only one of the 10 patients known to have been tested. Ten patients were treated with amphotericin B, 11 with ketoconazole, one with fluconazole and eight underwent surgery. While amphotericin B was used in eight of the 10 earliest treated cases. ketoconazole was administered in 10 of the 13 more recent cases. Of the patients for whom follow-up data have been obtained, 21 are reported cured (one of whom was not treated) and one patient died of another cause. This survey confirms that blastomycosis is a rare disease in this endemic area and that patterns of therapy are changing.

Key Words: Blastomyces dermatitidis, Blastomycosis, Quebec

\section{La blastomycose au Québec (1981-90): rapport de 23 cas et revue des cas publiés provenant du Québec}

RÉSUMÉ: De 1981 à 1990, 23 cas de blastomycose nous ont été signalés dans le cadre d'une enquête menée au Québec. Treize patients résident au sud du fleuve St-Laurent et 10 au nord. On remarque deux petits foyers dans les régions de Sherbrooke et Québec. Le ratio homme-femme est de 1.6:1 et l'âge médian de 47 ans, variant de 26 à 77 ans. Une atteinte des poumons est observée dans 19 cas et pour 11 de ceux-ci, il s'agit du seul site impliqué. On signale 11 atteintes cutanées, trois osseuses et une du système nerveux central. Le diagnostic est confirmé par culture dans 21 cas et par histopathologie pour les deux autres cas. Des 21 cas cultivés, Blastomyces dermatitidis est isolé 12 fois des poumons, neuf foịs de la peau et une fois des os et du cerveau. Les tests de sérodiagnostic par immunodiffusion ou fixation du complément sont

Laboratoire de santé publique du Québec, Sainte-Anne-de-Bellevue, Québec, Hôpital du St-Sacrement, Québec, Québec and Centre hospitalier de l'Université de Sherbrooke, Fleurimont, Québec

Correspondence and reprints: Mr G St-Germain, Laboratoire de santé publique du Buébec, Sainte-Anne-de-Bellevue, Buébec,

Québec H9X 3R5. Telephone (514) 457-2070, Fax (514) 457-6346

Received for publication February 26, 1992. Accepted April 24, 1992 
négatifs pour les 10 patients chez lesquels on rapporte avoir effectué ces épreuves. Dix patients ont été traités avec l'amphotéricine B, 11 avec le kétoconazole et un avec le fluconazole. Dans huit cas, on a eu recours à la chirurgie. Alors que l'amphotéricine B est utilisée pour le traitement de huit des 10 cas les plus anciens, le kétoconazole a été administré dans 10 des 13 cas les plus récents. Parmi les patients pour lesquels nous avons obtenu un suivi, 21 sont rapportés guéris, dont 1 sans traitement; un patient est décédé d'autres causes. Cette enquête confirme que la blastomycose est une maladie rare dans cette région endémique et qu'un changement important s'est opéré dans le choix du traitement.

$\mathrm{B}$ LASTOMYCOSIS IS A SYSTEMIC INFECTION CAUSED BY THE dimorphic fungus Blastomyces dermatitidis. Primary infection presumably occurs following inhalation of conidia into the lungs. The spectrum of illness that can result is variable and ranges from asymptomatic or self-limited pulmonary infection to chronic or rapidly fatal illness involving multiple organ systems $(1,2)$. In nature, the organism appears to be a soil saprophyte; the conidia apparently become airborne when the soil is disturbed. A few outbreaks, mostly associated with outdoor activities, have provided clues to the natural habitat of the organism, but many enigmas remain to be solved concerning growth and sporulation of $B$ dermatitidis in the environment $(3,4)$.

Cases of blastomycosis have been reported from all continents but are mostly prevalent in endemic areas of the United States, such as the Mississippi river basin, the south central and south eastern regions, and the Great Lakes area. The disease also is found in Canada where most cases have been reported from Quebec, Ontario and Manitoba $(5,6)$. The authors describe 23 cases of blastomycosis diagnosed in Quebec from 198190. A review of cases published from Quebec also is presented.

\section{MATERIALS AND METHODS}

Survey: A survey was undertaken to estimate the number of cases of blastomycosis diagnosed in Quebec from 1981-90. During that period, 20 strains/cases of $B$ dermatitidis were received for confirmation at the Quebec Public Health Laboratory. To obtain demographic and clinical data for each of these cases, questionnaires were mailed to the 12 hospital laboratories that had sent these strains. The information requested included age, sex, residence, clinical manifestations, microbiology, serology, histopathology and radiology results, treatment and outcome. Infectious disease physicians from these hospitals (and from teaching hospitals throughout the province) were asked to inform the authors of any other cases of blastomycosis diagnosed during the study period. A confirmed case of blastomycosis was defined by either a positive culture of the organism from

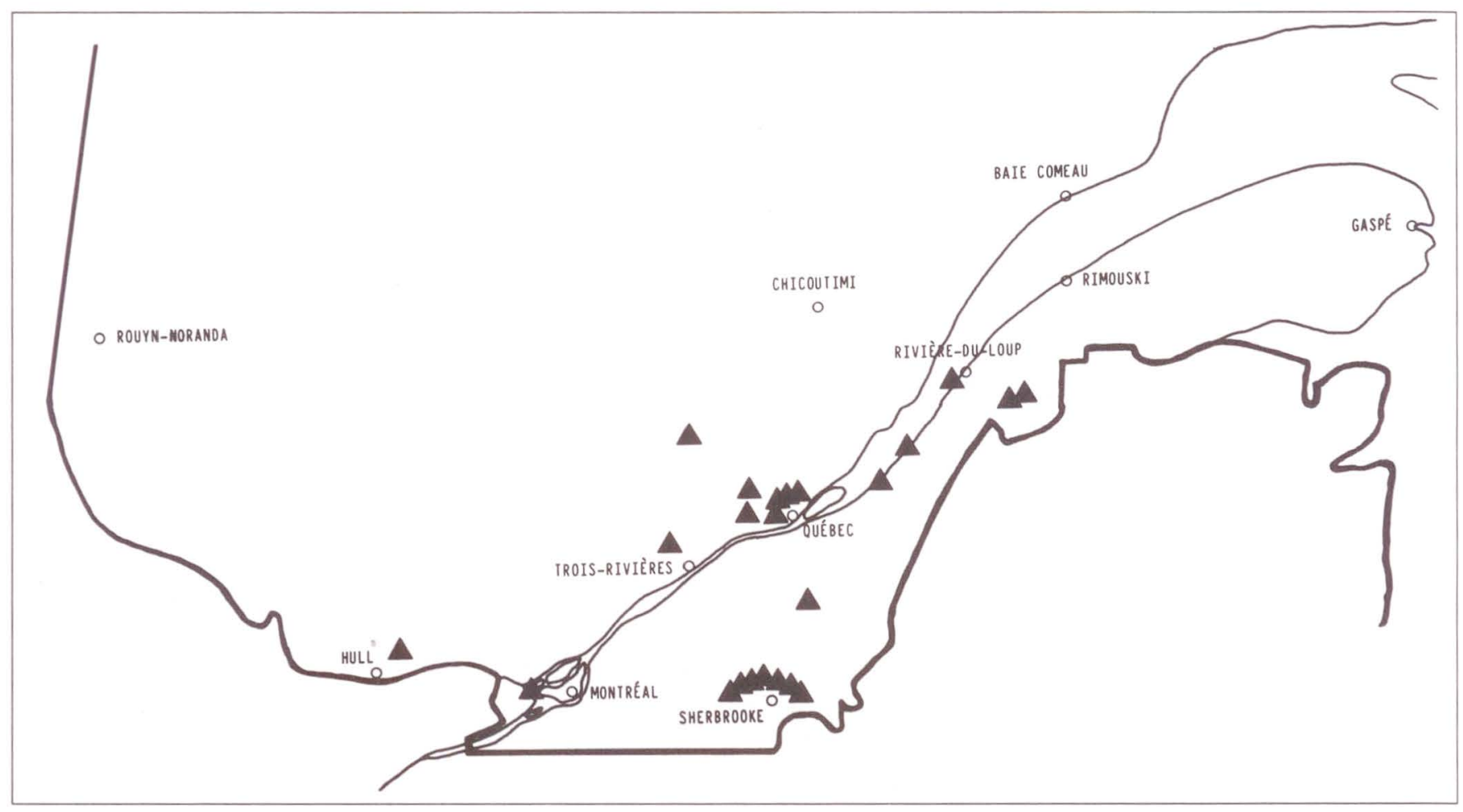

Figure 1) Geographical distribution of 23 cases of blastomycosis diagnosed in Quebec from 1981 to 1990. $\mathbf{\Delta}$ Individual cases 
TABLE 1

Cases of blastomycosis diagnosed in Quebec from 1981 to 1990

\begin{tabular}{|c|c|c|c|c|c|}
\hline Year & Age (sex) & $\begin{array}{l}\text { Clinical } \\
\text { manifest- } \\
\text { ations }\end{array}$ & $\begin{array}{c}\text { Isolation } \\
\text { sites }\end{array}$ & $\begin{array}{l}\text { Treat- } \\
\text { ment }\end{array}$ & $\begin{array}{l}\text { Out- } \\
\text { come }\end{array}$ \\
\hline 1981 & 77 (Male) & $P, C$ & $\mathrm{NC}$ & A,S & $\mathrm{Cu}$ \\
\hline 1982 & 36 (Male) & $\mathrm{P}$ & $P$ & $S$ & $\mathrm{Cu}$ \\
\hline 1982 & 58 (Male) & $P$ & $\mathrm{P}$ & $A$ & $D$ \\
\hline 1983 & 64 (Male) & C & C & K & $\mathrm{Cu}$ \\
\hline 1983 & 44 (Female) & c & C & A & $\mathrm{Cu}$ \\
\hline 1983 & 63 (Female) & $P, C$ & C & $A, S$ & $\mathrm{Cu}$ \\
\hline 1983 & 45 (Male) & $\mathrm{P}$ & $P$ & $A$ & $\mathrm{Cu}$ \\
\hline 1984 & 57 (Male) & $P$ & P & A,S & $\mathrm{Cu}$ \\
\hline 1984 & 29 (Female) & $P$ & $P$ & A & $\mathrm{Cu}$ \\
\hline 1985 & 56 (Male) & $P$ & $P$ & A & $\mathrm{Cu}$ \\
\hline 1986 & 53 (Male) & $P$ & $P$ & * & * \\
\hline 1986 & 42 (Male) & $P$ & $P$ & $K, S$ & $\mathrm{Cu}$ \\
\hline 1988 & 43 (Male) & P.C,O & $\mathrm{C}, \mathrm{O}$ & $\mathrm{K}, \mathrm{S}$ & $\mathrm{Cu}$ \\
\hline 1988 & 53 (Female) & $P$ & $P$ & K & $\mathrm{Cu}$ \\
\hline 1988 & 46 (Female) & $P$ & $\mathrm{P}$ & None & $\mathrm{Cu}$ \\
\hline 1988 & 47 (Female) & $P, C, O$ & C & K & $\mathrm{Cu}$ \\
\hline 1988 & 45 (Male) & P,C,O & C & $A, K$ & $\mathrm{Cu}$ \\
\hline 1989 & 76 (Male) & CNS & CNS & $A, F, S$ & $\mathrm{Cu}$ \\
\hline 1989 & 71 (Female) & $P, C$ & $P, C$ & $\mathrm{~K}, \mathrm{~S}$ & $\mathrm{Cu}$ \\
\hline 1990 & 44 (Male) & $P, C$ & C & K & $\mathrm{Cu}$ \\
\hline 1990 & 47 (Female) & $P, C$ & $\mathrm{P}$ & K & $\mathrm{Cu}$ \\
\hline 1990 & 26 (Female) & C & C & K & $\mathrm{Cu}$ \\
\hline 1990 & 33 (Male) & $\mathrm{P}$ & NC & K & $\mathrm{Cu}$ \\
\hline
\end{tabular}

*Unknown: A Amphothericine B; C Cutaneous; CNS Central nervous system: Cu Cured; D Deceased; F Fluconazole; K Ketoconazole; NC Not cultured; O Osseous; P Pulmonary; S Surgery

a clinical specimen or by histopathological tissue demonstration.

Identification of strains: Sporulation of the mold form was observed on modified Sabouraud dextrose agar at $25^{\circ} \mathrm{C}$, and conversion to the yeast phase was performed on brain-heart infusion agar and blood agar at $37^{\circ} \mathrm{C}$. Strains were also tested with exoantigen reagents (Nolan; Scott Biological Laboratories Inc, Georgia) and a molecular probe (GenProbe Inc, California). These reagents were used according to manufacturers' instructions.

Review of Quebec publications: Case reports published from Quebec were sought through Medline and the indexes of local medical journals. A case was considered valid when the description of the organism isolated or seen in tissue was compatible with $B$ dermatitidis.

\section{RESULTS}

Twenty-three confirmed cases of blastomycosis were identified. Median age of patients was 47 years (range 26 to 77 ), with a male to female ratio of 1.6:1. Geographical distribution is shown in Figure 1. Demographic and clinical data for individual patients are presented in Table 1 . Of the 21 culture-positive cases, $B$ dermatitidis was isolated 12 times from lungs, nine

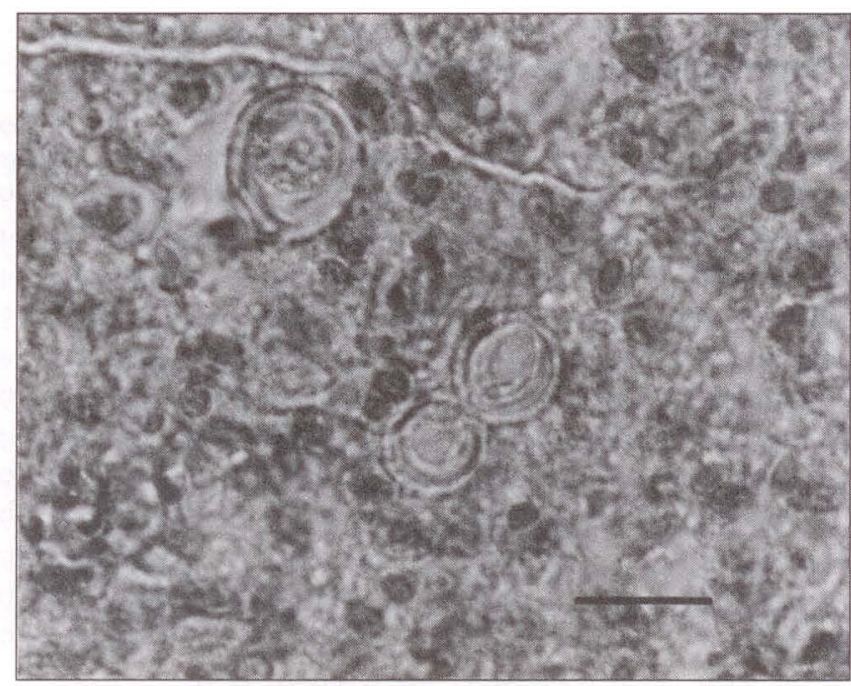

Figure 2) Hematoxylin-eosin stained skin biopsy specimen from the first case (1981). Typical broad-based budding yeast cells of Blastomyces dermatitidis are shown. Bar is $10 \mu \mathrm{m}$

times from skin, and once each from bones and brain. Overall, histopathological proof was found in 19 cases and suggestive radiological findings in 16 . The complement fixation and/or immunodiffusion tests had been performed for 10 patients; only one positive complement fixation result was obtained. In this series, the prognosis was good with no deaths nor relapses reported. One patient died of another cause.

Typical mold and yeast forms (2) were observed for all 20 strains identified at the Quebec Public Health Laboratory. The exoantigen test was positive for each of these strains, but up to $60 \%$ of strains, initially grown on agar media, required repeated testing or culture in broth to obtain a positive test. On the other hand, all 20 strains were rapidly and accurately identified by molecular probe. In the two cases in which the disease was diagnosed by histopathology only, the organism was readily identified by its distinctive thick-walled yeast cells producing broad-based buds (Figure 2).

The results of the literature search for case reports from $\mathrm{Guebec}$ and their rating are presented in Table 2. Of the 48 cases found, 13 were considered questionable.

\section{DISCUSSION}

Blastomycosis was first described by Gilchrist in 1897. The first Canadian case report was published by Primrose (7) in 1906 and the first report from Quebec was written by Shepherd and Rhea (8) in 1911. From 1911-40, case reports were published by McKenty (9), Gaumond (10), Beregoff-Gillow (11) and Nadeau (12). As pointed out by Starrs (13), many of these earlier reports were, at best, questionable because they lacked sufficient evidence to establish a proven or a presumptive diagnosis - indeed, some were based on clinical information only. As the disease became better known 
TABLE 2

Blastomycosis case reports from Quebec (1911-80)

\begin{tabular}{|c|c|c|c|c|c|c|c|c|c|}
\hline $\begin{array}{l}\text { Author } \\
\text { (reference) }\end{array}$ & Year & $\begin{array}{c}\text { Patient } \\
\text { (age in years) }\end{array}$ & Sex & $\begin{array}{c}\text { Year } \\
\text { diagnosed }\end{array}$ & $\begin{array}{c}\text { Clinical } \\
\text { manifestations }\end{array}$ & $\begin{array}{l}\text { Diagn } \\
\text { culture }\end{array}$ & $\begin{array}{l}\text { osis by: } \\
\text { histology }\end{array}$ & Outcome & $\begin{array}{c}\text { Case report } \\
\text { rating }\end{array}$ \\
\hline McKenty (9) & 1915 & $\mathrm{AV}(48)$ & Male & $N G$ & C & No & Yes & NG & $Q$ \\
\hline McKenty (9) & 1915 & NG (43) & Male & 1910 & $\mathrm{C}, \mathrm{O}$ & Yes & Yes & $\mathrm{D}$ & $Q$ \\
\hline McKenty (9) & 1915 & $D(32)$ & Female & $N G$ & $\mathrm{C}$ & No & Yes & NG & $Q$ \\
\hline Nadeau (12) & 1940 & ZL (26) & Male & 1940 & CNS & Yes & Yes & $N G$ & $Q$ \\
\hline Lamoureux (14) & 1948 & RSt-G (60) & Female & 1947 & 0 & No & Yes & NG & $A$ \\
\hline Simard (15) & 1953 & NG (52) & Male & 1950 & P,O & Yes & Yes & $\mathrm{D}$ & $A$ \\
\hline Simard (15) & 1953 & $M(41)$ & Male & 1950 & $\mathrm{C}$ & Yes & Yes & NG & $A$ \\
\hline Simard (15) & 1953 & $\mathrm{MM}(30)$ & Male & 1951 & C.P & Yes & Yes & NG & $A$ \\
\hline Gaumond (18) & 1953 & $\mathrm{FL}(48)$ & Male & 1943 & $\mathrm{C}$ & No & Yes & NG & $Q$ \\
\hline Gaumond (18) & 1953 & $A Q(43)$ & Male & 1943 & $\mathrm{C}$ & Yes & Yes & $\mathrm{Cu}$ & $A$ \\
\hline Gaumond (18) & 1953 & EP (55) & Male & 1945 & C & No & Yes & $\mathrm{Cu}$ & $Q$ \\
\hline Gaumond (18) & 1953 & $\mathrm{AL}(34)$ & Male & 1945 & $\mathrm{C}$ & Yes & Yes & $N G$ & $A$ \\
\hline Gaumond (18) & 1953 & RSt-P (30) & Male & 1946 & C & No & Yes & $\mathrm{Cu}$ & $Q$ \\
\hline Gaumond (18) & 1953 & GG (31) & Male & 1947 & C & No & Yes & $\mathrm{Cu}$ & $Q$ \\
\hline Gaumond (18) & 1953 & $A B(50)$ & Male & 1949 & C & Yes & Yes & $\mathrm{Cu}$ & A \\
\hline Gaumond (18) & 1953 & $\operatorname{MAR}(52)$ & Male & 1951 & C & Yes & Yes & NG & $A$ \\
\hline Giroux (19) & 1955 & $A B(52)$ & Male & 1954 & P.O & Yes & Yes & $D$ & A \\
\hline Poirier (20) & 1955 & PC (46) & Male & 1946 & C & Yes & No & $\mathrm{Cu}$ & $Q$ \\
\hline Grandbois (25) & 1963 & $\mathrm{AL}(34)$ & Male & 1961 & $P$ & No & Yes & $N G$ & $A$ \\
\hline Boulet (26) & 1980 & ${ }^{*}(21$ to 62$)$ & Male & $1957-78$ & $P(15), C(6), O(3)$ & Yes (3) & Yes (15) & Cu (15) & A \\
\hline
\end{tabular}

*Fifteen cases reported but not on an individual basis (all patients were male, average age was 42 years); Numbers in square brackets refer to number of cases; A Accepted; C Cutaneous; CNS Central nervous system; Cu Cured; D Deceased; GU Genito-urinary; Q Questionable; NG Not given; O Osseous: P Pulmonary

and laboratory expertise more readily available, more complete information was provided in case reports. In establishing the number and validity of these cases, some difficulties were encountered as most reports were published in local medical journals not listed in Index Medicus. Furthermore, some individual cases were reported in as many as three different journals. Of the 48 cases listed in Table $2,27 \%$ were found questionable. Among the 35 cases with a conclusive diagnosis, the male to female ratio was 10.7:1 and the average age was 43.7 years.

In this 1981-90 survey, two geographical clusters of cases were found in and around the Quebec City and Sherbrooke areas (along with Montreal, they are the most densely populated areas in the province). The
1986 census in Canada established the population of the province at $6,500,000$. Only one case was reported from the Montreal area (which has $45 \%$ of the population of the province). Although $B$ dermatitidis has never been isolated from the environment in Quebec, it is apparent that the fungus is more prevalent in the wooded or rural areas in the vicinity of the first two locations. It is worth mentioning also that five cases were found in patients residing in the low density populated area in between Quebec City and Rivière-duLoup (along the south shore of the St Lawrence River), indicating the presence of the fungus in that region.

Blastomycosis was previously thought to occur more often in males than in females. The male to female ratio derived from the 1911-80 review of case reports from 
Quebec is 10.7:1. However, the 1981-90 survey produced a ratio of 1.4:1 indicating, as other recent studies have done, that occupation and outdoor activities were mainly responsible for the differences observed previously $(3,4)$.

Clinical manifestations in the presented 23 patients are similar to those described in cases reported from the more highly endemic areas of North America, with pulmonary infections occurring most often, followed by cutaneous involvement (1). Serodiagnostic tests are not known to play an important role in the diagnosis of blastomycosis $(1,27)$. Although the immunodiffusion test is reported to be highly specific, it lacks sensitivity. The complement fixation test lacks sensitivity and specificity. In this series, neither of these tests were found to be useful - only one patient out of 10 tested positive. Radiological findings were often useful but diagnosis was obtained mainly by culture and histopathology.

Although identification of $B$ dermatitidis usually is obtained readily by conversion of the mold form to the yeast form, the fungus can also be identified by an exoantigen test or a molecular probe. The authors' experience with exoantigen testing indicates a lack of sensitivity with strains grown on agar slopes compared with broth cultures. The molecular probe was highly sensitive. Both of these tests are reported to be very specific, although the probe is known to cross-react with Paracoccidioides brasiliensis.

Clinical trials for the treatment of blastomycosis with

ACKNOWLEDGEMENTS: The authors thank Drs G Brochu, Hôpital Laval, S Claveau, Hôtel-Dieu de Québec, L Deschénes, Hôpital Laval, M Germain, Hôpital Laval, S Lambert, Hôpital Enfant-Jésus, C Lemieux, Hôpital Notre-Dame, V Fontaine, Hôtel-Dieu de Sherbrooke and A Vincent, Hôtel-Dieu de Lévis, for providing data for study. The authors also thank D Beauchesne for excellent technical assistance.

\section{REFERENCES}

1. Chapman SW. Blastomyces dermatitidis. In: Mandell GL, Douglas RG, Bennett JE, eds. Principles and Practice of Infectious Diseases, 3rd edn. New York: Churchill Livingston, 1990:1999-2008.

2. Rippon JW. Medical Mycology: The Pathogenic Fungi and Pathogenic Actinomycetes, 3rd edn. Philadelphia: WB Saunders, 1988:474-505.

3. Klein BS, Vergeront JM, Weeks RJ, et al. Isolation of Blastomyces dermatitidis in soil associated with a large outbreak of blastomycosis in Wisconsin. N Engl J Med 1986;314:529-34.

4. Klein BS, Vergeront JM, DiSalvo AF. Two outbreaks of blastomycosis along rivers in Wisconsin. Am Rev Respir Dis $1987 ; 136: 1333-8$.

5. Sekhon AS, Bogorus MS, Sims HV. Blastomycosis: Report of three cases from Alberta with a review of Canadian cases. Mycopathologia 1979;68:53-63.

6. Kane J, Righter J, Krajden S, Lester RS. Blastomycosis: A new endemic focus in Canada. Can Med Assoc $J$ 1983;129:728-31.

7. Primrose A. Blastomycosis of the skin in man. Edinburgh Med J 1906:20:215.

8. Shepherd FJ, Rhea LI. A fatal case of blastomycosis. J Cutaneous Dis 1911;29:588-94. ketoconazole performed in the early 1980s showed that this drug is a viable alternative to amphotericin B to treat mild to moderate forms of blastomycosis $(28,29)$. The drug was released on the Canadian market in December 1984. Not surprisingly, this survey shows that amphotericin B was used in eight of the 10 earliest treated cases whereas ketoconazole was administered in nine of the 10 more recent ones. Although ketoconazole has now been used for many years to treat moderate forms of blastomycosis, amphotericin B therapy still remains necessary for patients with life-threatening or CNS diseases, as well as for patients who do not respond to ketoconazole treatment or who cannot tolerate the drug (1). In case 18 (infection of the CNS was diagnosed), amphotericin B was used in combination with fluconazole, resulting in cure. Studies are ongoing to assess the efficacy of this latter drug and others such as itraconazole $(30,31)$. As these drugs are reputedly less toxic than ketoconazole, it is likely that recommendations for treatment will change again in the '90s. Indeed, some clinicians now consider itraconazole as the drug of choice (32).

\section{CONCLUSIONS}

Blastomycosis is a rare disease in Quebec (where it is found mainly in the Quebec City and Sherbrooke areas), averaging two to four cases per year. Although early reported cases were treated with amphotericin B, more recently reported cases were treated with ketoconazole.

9. McKenty FE, Morgan D. Blastomycosis. Ann Surg 1915;61:513-8.

10. Gaumond E. Blastomycose généralisée mortelle. Bull Soc Med Hop Univ Qué 1933;322-30.

11. Beregoff-Gillow P. The importance of early diagnosis in mycotic diseases, with special reference to blastomycosis. Can Med Assoc J 1936;34:152-5.

12. Nadeau H. Méningite \& Blastomyces. Laval médical 1940;5:364-70.

13. Starrs RA, Klotz MO. North American Blastomycosis (Gilchrist's disease). Arch Intern Med 1948;82:29-53.

14. Lamoureux M, Leclerc G. Blastomycose. Union Méd Can 1948;77:1002-3.

15. Simard LC, Gélinas-McKay C, Germain R. Quatre cas de blastomycose nord-américaine. Union Méd Can 1953:82:276-81.

16. Leduc A. Blastomycoses de l'Amérique du Nord (Maladie de Gilchrist). Union Méd Can 1953;82:282-3.

17. Leduc A. Mycoses pulmonaires. Union Méd Can 1953;82:790-3.

18. Gaumond E. Onze cas de blastomycose nord-américaine dans la région de Québec. Laval Médical 1953;18:1319-44.

19. Giroux M, Dessureault R. Blastomycosse gênéralisée. Laval Médical 1955;20:1326-32.

20. Poirier P. Blastomycose Nord-Américaine (Maladie de Gilchrist). Union Méd Can 1955;84:247.

21. Doray M, Guy R, Dionne P, et al. Un cas de Blastomycose nord-américaine traitée avec succès par la 2-hydroxystilbamidine. Union Méd Can 1957;86:182-7.

22. Grandbois J, Giroux M, Gravel J, Beaulieu M. La 2-hhydroxystilbamidine dans le traitment de la blastomycose nord-américaine. Laval Médical 1957;24:165-83. 
23. Watson SH, Moore S, Blank F. Generalized North American blastomycosis. Can Med Assoc J 1958;78:35-40.

24. Grandbois J. The modern treatment of North American blastomycosis. Can Med Assoc J 1958;79:828-32.

25. Grandbois J. La blastomycose nord-américaine au Canada. Laval Médical 1963;34:714-30.

26. Boulet LP, Cormier Y. La blastomycose nord-américaine: À propos de 15 cas. Vie Méd Canada français 1980;9:685-95.

27. Goldstein E, Koo J. Immunologic tests in the diagnosis of pulmonary infection. Clin Rev Allergy 1990;8:229-52.

28. National Institute of Allergy and Infectious Diseases Mycoses Study Group. Treatment of blastomycosis and histoplasmosis with ketoconazole:
Results of a prospective randomized clinical trial. Ann Intern Med 1985;103:861-72.

29. Saag MJ, Dismukes WE. Treatment of histoplasmosis and blastomycosis. Chest 1988;93:848-51.

30. Saag M, Bradsher R, Chapman S, et al. Itraconazole therapy for blastomycosis, histoplasmosis and sporothricosis (abstract 574). 28th Interscience Conference on Antimicrobial Agents and Chemotherapy. Washington, 1988.

31. Stevens DA, Brummer E, McEwen JG, Perlman AM. Comparison of fluconazole and ketoconazole in experimental murine blastomycosis. Rev Inf Dis 1990;12(Suppl3):S304-6.

32. Bradsher RW. Blastomycosis. Clin Inf Dis 1992:14:82-90. 


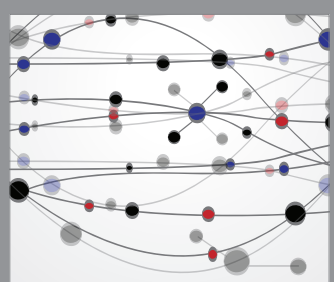

The Scientific World Journal
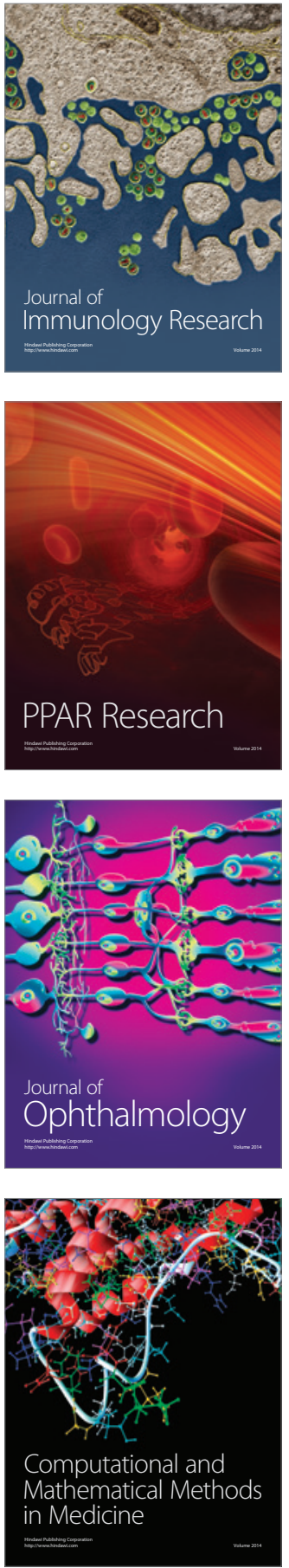

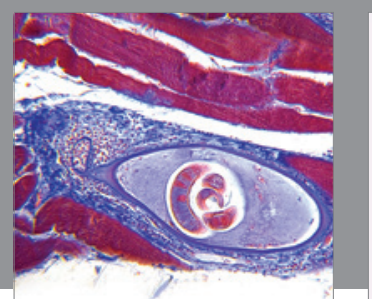

Gastroenterology Research and Practice

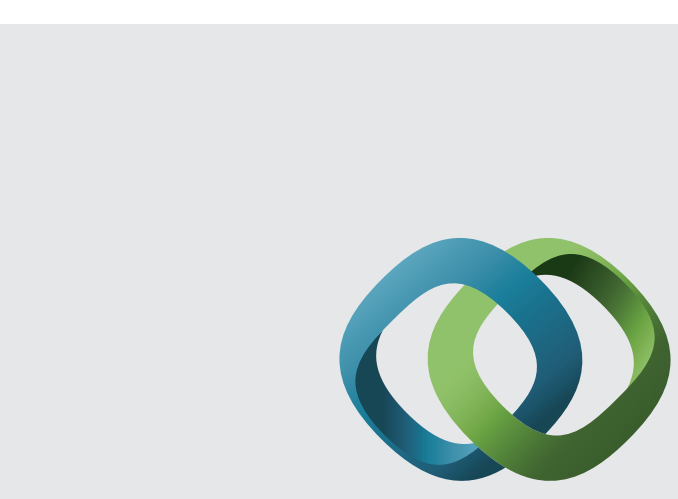

\section{Hindawi}

Submit your manuscripts at

http://www.hindawi.com
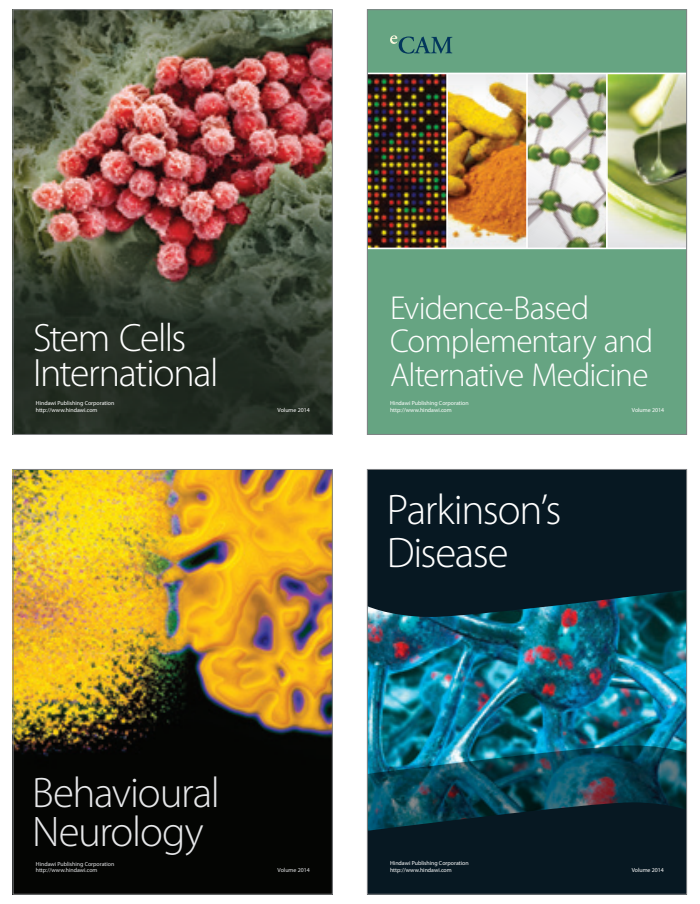
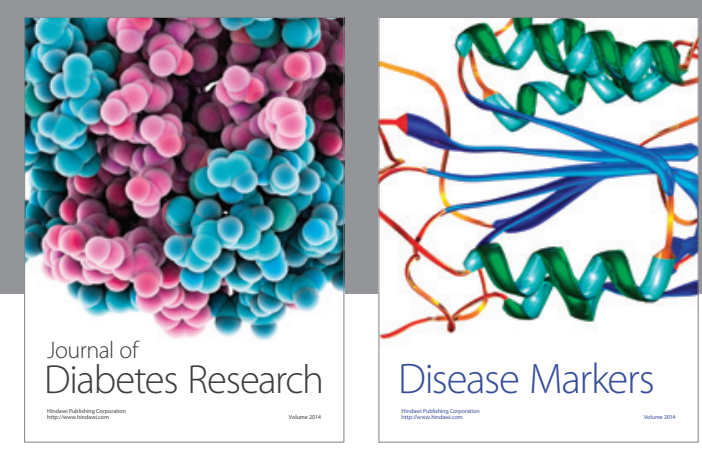

Disease Markers
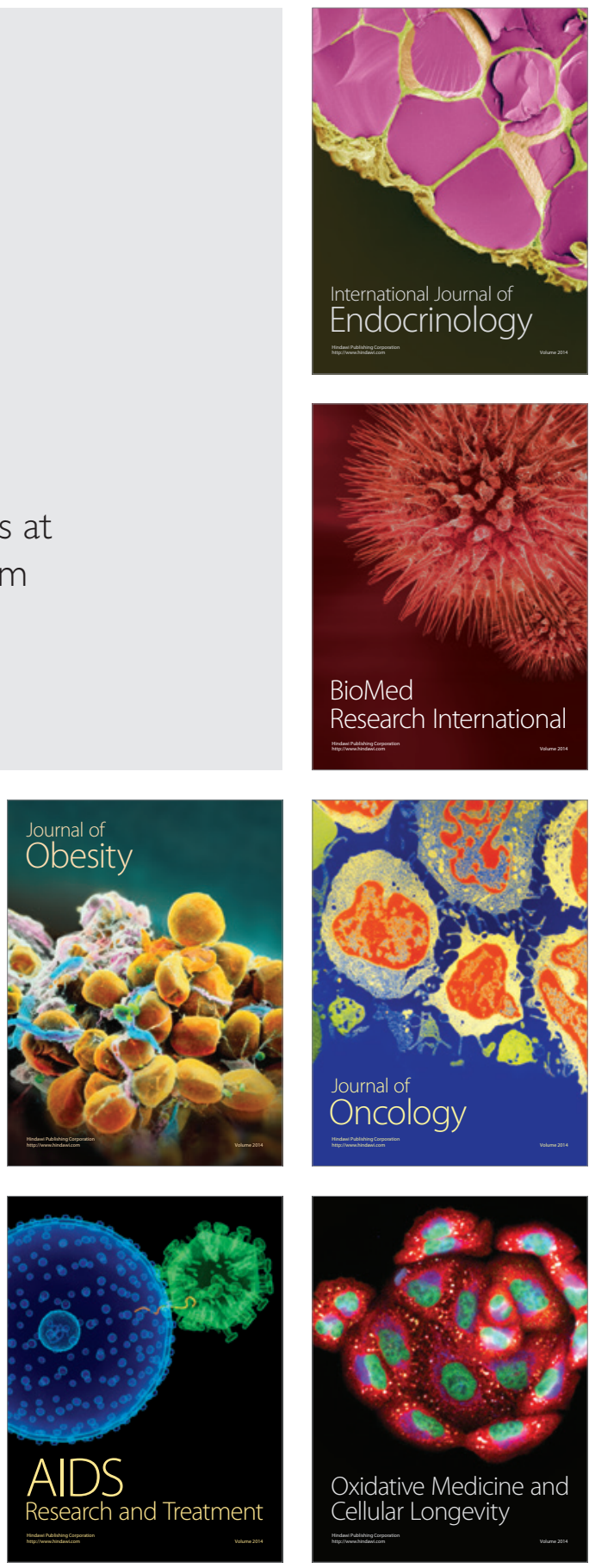